\title{
Does Previous Open Nephrolithotomy Affect the Success and Complications Rate of Percutaneous Nephrolithotomy?
}

\author{
Böbrek Taşı Nedeni ile Açık Taş Cerrahisi Geçirmiş Olmak, Perkütan \\ Nefrolitotomi Başarısını ve Komplikasyon Oranlarını Etkiler mi?
}

\author{
Furkan Dursun1, Hasan Soydan2, Ömer Yılmaz2, Ercan Malkoç22, Ferhat Ateş2, Temuçin Şenkul2 \\ 1 Gümüşsuyu Military Hospital, Clinic of Urology, Istanbul, Turkey \\ 2Gülhane Military Medical Academy Haydarpaşa Training Hospital, Clinic of Urology, İstanbul, Turkey
}

\begin{abstract}
What's known on the subject? and What does the study add?
The results obtained in previous studies are inconclusive and some of them claim that previous surgeries affect the success of the percutaneous nephrolithotomy (PCNL). However, there are also a few studies claiming that PCNL is a good option even after an open surgery. This study adds a new group of patients to the data of the literature about the safety of PCNL in secondary cases.
\end{abstract}

\begin{abstract}
Objective

To investigate the differences between the results of percutaneous nephrolithotomy (PCNL) for stone relapse in patients who previously underwent open surgery for renal stones and those in patients undergoing surgery for the first time.
\end{abstract}

\section{Materials and Methods}

Patients who underwent PCNL for renal stones bigger than $2 \mathrm{~cm}$ between the years 2009 and 2012 were evaluated. Stone size, length of the procedure, number of access, period of catheterization, length of hospital stay, complications, and stone-free rates were evaluated.

\section{Results}

A total of 64 patients included in the study. Twenty-seven had previously undergone open surgery for renal stones (group 1) and 37 underwent surgery for the first time (group 2). There was no significant difference between the groups in age and stone size. Seven (25.9\%) patients in group 1 and $6(18.2 \%)$ patients in group 2 had more than one access $(p=0.628)$. In group $1 ; 2$ patients $(7.4 \%)$ had grade 2 and 3 patients $(11.1 \%)$ had grade 3 complications. In group 2; 4 patients (10.8\%) had grade 2 and 7 patients (18.9\%) had grade 3 complications. The stone-free rate was $14(51.8 \%)$ in group 1 and $23(62.2 \%)$ in group 2 . The rate of clinically insignificant residual stones was $8(29.6 \%)$ in group 1 and $5(13.5 \%)$ in group 2. The success rate of PCNL procedure in group 1 was $81.5 \%$ and $75.7 \%$ in group $2(\mathrm{p}=0.161)$.

Conclusion

PCNL is a good option for patients who had a previous open surgery for renal stones as well as for patients undergoing surgery for the first time.

Keywords

Percutaneous nephrolitotomy, open nephrolitotomy, complication

\section{ÖZ}

\section{Amaç}

Daha önce böbrek taşı nedeniyle açık cerrahi geçiren hastaların nüks eden taşlarında perkütan nefrolitotomi sonuçlarını değerlendirmek ve ilk kez taş nedeni ile perkütan nefrolitotomi (PNL) yapılan hastalarla karşılaştırmaktır.

\section{Gereç ve Yöntem}

2009-2012 yılları arasında kliniğimizde $>2 \mathrm{~cm}$ böbrek taşı nedeni ile PNL yapılan hastalar retrospektif olarak değerlendirildi. Hastalar taş boyutu, skopi süresi, giriş sayısı, nefrostomi kalış süresi, görülen komplikasyonlar, transfüzyon ihtiyacı ve postoperatif taşsızlık durumuna göre değerlendirildi. Veriler benzer taş yükü olan ve ilk kez taş nedeniyle cerrahi yapılan hasta grubu ile karşılaştırıldı.

Bulgular

Daha önce açık cerrahi yapılmış 27 hasta (grup 1) ve ilk kez perkütan cerrahi yapılan 37 hasta (grup 2) olmak üzere toplam 64 hasta değerlendirilmeye alındı. Gruplar arasında hasta yaşı ve taş boyutu açısından anlamlı fark yoktu. Grup 1 'de $7(\% 25,9)$ hastaya, grup 2 'de ise $6(\% 18,2)$ hastaya işlem esnasında birden fazla giriş yapıldı $(p=0,628)$. Clavien skorlama sistemine göre 1 . grupta 2 hastada $(\% 7,4) 2$. derece, 3 hastada $(\% 11,1) 3$. derece komplikasyonlar görülürken; 2. grupta 4 hastada $(\% 10,8) 2$. derece ve 7 hastada $(\% 18,9) 3$. derece komplikasyonlar görüldü. Taşsızlık oranı birinci ve ikinci grupta sırasıyla $14(\% 51,8)$ ve $23(\% 62,2)$ iken klinik anlamsız rezidüel taş oranı sırasıyla $8(\% 29,6)$ ve $5(\% 13,5)$ idi. PNL başarı oranı 1. grup için $\% 81,5,2$. grup için $\% 75,7$ olarak hesaplandı $(p=0,161)$.

\section{Sonuç}

PNL, daha önce taş nedeniyle açık cerrahi geçirmiş olan hastalarda, ilk kez yapılan hastalarla benzer komplikasyon ve taşsızlık oranları ile iyi bir seçenek olarak uygulanabilir.

\section{Anahtar Kelimeler}

Perkütan nefrolitotomi, açık cerrahi, komplikasyon

\section{Correspondence}

Furkan Dursun MD, Gümüşsuyu Military Hospital, Clinic of Urology, İstanbul, Turkey

Phone: +90 21225185 00/31-33 E-mail: drfurkandursun@hotmail.com Received: 05.11.2015 Accepted: 10.11.2015 


\section{Introduction}

Percutaneous nephrolithotomy (PCNL) is a well established, minimally invasive treatment modality for large renal calculi over the past 30 years. With surgeon experience and improvements in instruments and lithotripsy technology, PCNL becomes the recommended primary treatment option for patients with large volume or staghorn renal calculi, yielding stone-free rates of $>90 \%(1,2)$.

Advances in stone therapy have made open surgery almost obsolete (3). PCNL is cheaper, has lower morbidity and provides better postoperative patient comfort (4). Thus, the incidence of open stone surgery is $\sim 1.5 \%$ of all stone removal interventions in developed countries. However, in recent years, it has dropped from nearly 26\% to $3.5 \%$ in developing countries $(5,6)$.

Some authors have reported higher rate of treatment failure and complications in patients with past history of open surgery due to the retroperitoneal scar tissue formation around the kidney and distortion of the anatomy of collecting system. However, there are also a few studies reporting no difference in success and complications rates. The data about this topic is not clear $(7,8,9,10,11)$. In this study, we retrospectively reviewed our PCNL results in patients who had previously undergone open surgery for renal stones and compared them with those in patients undergoing PCNL for the first time.

\section{Materials and Methods}

Sixty-four patients, who underwent PCNL for renal stones between the years 2009 and 2012, were evaluated retrospectively. The patients were divided into two groups according to history of stone removal surgery. Those who had undergone open nephrolithotomy or pyelolithotomy were defined as group 1 and patients having stone surgery (PCNL) for the first time were included in group 2.

Considering the increased risk of complications, patients with comorbidities, such as chronic renal failure, abnormal clotting disorders, skeletal deformities, severe respiratory problems, diabetes mellitus, hypertension or cardiopulmonary diseases were excluded from this study.

Preoperative complete blood count, bleeding and coagulation profile, serum creatinine, and urine cultures were obtained for all patients. Radiologic evaluation included $x$-ray of kidney, ureter and bladder (KUB) and noncontrast computed tomography for all patients and intravenous urography when necessary. The stone size was determined by measuring the longest diameter of the stone.

After ensuring sterile urine, the patients underwent PCNL with standard protocol (12). After insertion of a ureteral catheter with cystoscopy, the patients were placed in the prone position and the puncture of the collecting system with access needle was done using C-armed fluoroscopy with or without pyelography. Especially at the beginning of the dilatation with $9 \mathrm{~F}$ dilatators, we had little difficulties due to fibrosis. A blunt dilation was made using a clamp to facilitate insertion and to extend the tract of the percutaneous access needle. After this step, with the help of the scar tissue on fixation of the kidney, remaining steps were done easily.

The tract was dilated and a 28/30 F Amplatz sheath was placed. Nephroscopy was performed with a rigid 26F nephroscope (Karl Storz) and the calculi were fragmented with pneumatic lithoclast. If needed, another puncture was made to achieve stone clearance. A 16F Malecot catheter was placed as nephrostomy tube into the renal pelvis or the punctured calyx at the end of the procedure in all patients. Stone clearance was confirmed intra-operatively by fluoroscopy.

Antibiotic prophylaxis was given to all patients. Serum creatinine levels and blood counts were obtained in all patients postoperatively. The urethral Foley catheter was removed on the first postoperative day. On postoperative day 2, KUB x-ray and antegrade nephrostogram were performed to assess the collecting system and residual stone before the nephrostomy tube was removed. If urine leak persisted for more than 24 hour, then DJ stent placement was done. PCNL procedure was considered successful if the patient was either stonefree or had any clinically insignificant residual stones (CIRFs), defined as $<2 \mathrm{~mm}$ and asymptomatic residual fragments.

Data on age, stone size, length of the procedure, number of access during surgery, period of catheterization, complications and peroperative blood counts were recorded. The modified Clavien grading system was used for evaluating perioperative and postoperative complications of PCNL (Table 1) (13).

Statistical analysis was performed using the $\times 2$-test and Student's $t$-test. The level of significance was defined as $p<0.05$.

\section{Results}

A total of 64 patients were included in the study. Twenty-seven had previously undergone open surgery for renal stones (group 1) and 37 had surgery for the first time (group 2). The average age in group 1 and group 2 was 38.4 years (17-75) and 38.9 years (20-74), respectively. The average stone size in group 1 and group 2 was 40 \pm 19.1 (20-110) $\mathrm{mm} 43.8 \pm 23.4(20-130) \mathrm{mm}$, respectively $(\mathrm{p}=0.559)$. The average scopy time at surgery was $10.4 \pm 6.4$ (2-23) minutes for group 1 and $11.6 \pm 6.5$ (4-27) minutes for group 2 ( $p=0.544$ ) (Table 2).

Seven (25.9\%) patients in group 1 and 6 (18.2\%) patients in group 2 had more than one access $(p=0.628)$. The average period of catheterization was $2.9 \pm 1.5(2-7)$ days in group 1 and $2.7 \pm 1.4(2-7)$ days in group $2(\mathrm{p}=0.217)$.

In group 1; 2 patients (7.4\%) had grade 2 and 3 patients (11.1\%) had grade 3 complications. In group 2; 4 patients (10.8\%) had grade 2 and 7 patients (18.9\%) had grade 3 complications according to the modified Clavien grading system ( $p=0.702)$.

The stone-free rate was $14(51.85 \%)$ in group 1 and $23(62.16 \%)$ in group 2. The rate of CIRFs was 8 (29.62\%) in group 1 and 5 (13.51\%) in group 2. The success rate of PCNL procedure in group 1 and group 2 was $81.5 \%$ and $75.7 \%$, respectively $(p=0.161)$.

\section{Discussion}

In the last 3 decades, open stone surgery has been replaced by minimally invasive approaches, such as extracorporeal shockwave lithotripsy, ureterorenoscopy and PCNL. Especially with the improvements in instruments and lithotripsy technology, PCNL becomes the primary treatment of choice for large-volume and staghorn renal calculi $(1,2)$. Patients with a previous open surgery for renal calculi have retroperitoneal scar tissue around the kidney and distortion of the collecting system anatomy. Because of the changes in the anatomy, PCNL may be more 


\section{Table 1. The modified Clavien grading system}

\begin{tabular}{|l|l|}
\hline Grade 1 & $\begin{array}{l}\text { Any deviation from the normal postoperative course without the need for pharmacologic treatment or surgical, endoscopic and } \\
\text { radiologic interventions. Allowed therappeutic regimens include drugs such as antiemetics, antipyretics, diuretics, electrolytes } \\
\text { and pyhsiotherapy }\end{array}$ \\
\hline Grade 2 & $\begin{array}{l}\text { Complications requiring pharmacologic treatment with drugs other than allowed for Grade 1 complications. Blood transfusions } \\
\text { and total parenteral nutrition are also included }\end{array}$ \\
\hline Grade 3 & $\begin{array}{l}\text { Complications requiring surgical, endoscopic or radiologic intervention } \\
\text { Grade 3a: Intervention not under general anesthesia } \\
\text { Grade 3b: Intervention under general anesthesia }\end{array}$ \\
\hline Grade 4 & $\begin{array}{l}\text { Life-threatening complications (including central nervous system complications) requiring intensive care unit stay } \\
\text { Grade 4a: Single-organ dysfunction (including dialysis) } \\
\text { Grade 4b: Multiorgan dysfunction }\end{array}$ \\
\hline Death of the patient 5 & \\
\hline
\end{tabular}

Table 2. Operative data of patients undergoing percutaneous nephrolithotomy

\begin{tabular}{|c|c|c|c|}
\hline & & Group $1(\mathrm{n}=27)$ & Group $2(n=37)$ \\
\hline Age & & $38.4(17-75)$ & $38.9(20-74)$ \\
\hline Stone size & & $\begin{array}{l}40.03 \pm 19.10 \mathrm{~mm} \\
(20-110 \mathrm{~mm})\end{array}$ & $\begin{array}{l}43.82 \pm 23.36 \mathrm{~mm} \\
(20-130 \mathrm{~mm})\end{array}$ \\
\hline Scope time & & $\begin{array}{l}10.36 \pm 6.45 \mathrm{~min} \\
(2-23 \mathrm{~min})\end{array}$ & $\begin{array}{l}11.63 \pm 6.46 \mathrm{~min} \\
(4-27 \mathrm{~min})\end{array}$ \\
\hline $\begin{array}{l}\text { Nephrostomy tube } \\
\text { Length of stay }\end{array}$ & & $\begin{array}{l}2.85 \pm 1.54 \text { days } \\
(2-7 \text { days })\end{array}$ & $\begin{array}{l}2.66 \pm 1.36 \text { days } \\
(2-7 \text { days })\end{array}$ \\
\hline Preoperative hemo & & $\begin{array}{l}13.88 \mathrm{~g} / \mathrm{dL}(11.3-15.6) \\
40.26 \text { (31.6-48.5) }\end{array}$ & $\begin{array}{l}14.34 \mathrm{~g} / \mathrm{dL}(10.4-17.2) \\
40.94(30.1-48.8)\end{array}$ \\
\hline Postoperative hem & & $\begin{array}{l}12.16 \mathrm{~g} / \mathrm{dL}(7.63-15.1) \\
35.08(22.7-43.9)\end{array}$ & $\begin{array}{l}12.67 \mathrm{~g} / \mathrm{dL}(7.9-15.8) \\
36.86(22-49.9)\end{array}$ \\
\hline Stone-free status & Stone-free & $14(51.85 \%)$ & $23(62.16 \%)$ \\
\hline & CIRF $^{*}$ & $8(29.62 \%)$ & $5(13.51 \%)$ \\
\hline & Residual stone & $5(18.51 \%)$ & $9(24.32 \%)$ \\
\hline
\end{tabular}

CIRF: Clinically insignificant residual stones

difficult or may have a higher complication rate. There are two reports of higher failure rates of PCNL in patients with a previous open surgery. PCNL failed in almost one third of patients who had a previous open surgery for renal stones, with a higher complication rate and a lower stone-free rate. However, these studies did not compare the groups according to the size or number of the stones $(14,15)$.

There are few studies on this subject with a similar design with our study. In these studies, the authors claimed that a history of an open stone surgery does not adversely affect the success or morbidity of PCNL, as we mentioned in our study $(7,8,9,10,16)$. Lojanapiwat $(16)$ compared 178 renal units with a previous open surgery and 178 without. There were no difference in technique or the success or complication rate. Also, Basiri et al. (7) compared the results of PCNL in 65 patients with a previous open surgery and 117 patients having a stone removal surgery for the first time and found no difference in success or complication rates. Sofikerim et al. (8) compared 27 patients who had previous renal surgery and 62 patients who had not undergone renal surgery. As we found in our study, there were no differences in operating time, intraoperative and postoperative complications, the number of accesses, or the stone-free rate.
Margel et al. (9) compared the results in 21 patients with previous open surgery and 146 without. They found that operation time, percentage of secondary procedures and the number of attempts to gain access were significantly higher in patients who had previously undergone open surgery. However, there were no difference in freestone rate and intraoperative or postoperative complication rate. Also, Tugcu et al. (10) found similar results about the success rate and complications in their study group of 55 patients with a previous open surgery and 105 patients who had no previous open surgery. Only the mean operative time was found significantly longer in patients with a history of open surgery.

The outcomes of PCNL can be evaluated in terms of success and complications rate. The success of PCNL can be expressed by the stone-free rates. Stone-free rates were found to be similar in different studies $(8,11,16)$. In our study, the stone-free rate in group 1 and in group 2 was $77.77 \%$ and $72.97 \%$, respectively $(p=0.153)$. The stone free-rate in our study was a little bit lower than in similar studies, but we assume that the mean stone size of more than $4 \mathrm{~cm}$ in patients in our study may explain this stone-free rate. 
The modified Clavien grading system was used for the first time in our study to evaluate the complications and there was no significant difference in complication rate between the two groups. In similar studies, the complications were not evaluated with the modified Clavien grading system. However, there were no difference between the groups in bleeding, one of the most common complications requiring transfusion, and the other complications $(7,8,9,10,11)$.

Previous open nephrolithotomy causes retroperitoneal scar tissue formation around the kidney which may adversely affect access of the needle and dilation of the tract. The distortion of collectingsystem anatomy may increase the number of renal access $(9,15)$. To avoid renal scar tissue, the supracostal approaches may be used (16). In our study, there were 7 patients in group 1 and 6 patients in group 2 who needed more than one access during PCNL and, the number of accesses to the kidney was similar in both groups $(p=0.628)$.

In previous studies, the mean operative time was found to be longer in patients who had previously undergone open nephrolithotomy $(9,10,11)$. In our study, we did not study the operative time but according to our data the scopy time during surgery was similar between the two groups. In various studies, the mean length of hospital stay was found to be similar in patients with and without a previous surgery $(7,10,11)$. In our study, we evaluated the period of catheterization. The patients were discharged 12 hours after removal of nephrostomy tube, if there was no urine leak. There was no significant difference in period of catheterization between the two groups.

The limitation of the present study is the small sample size. But the similarity in the stone size and location between the two groups as well as the use of the modified Clavien grading system to evaluate the complications are the advantages of the study.

In conclusion the data obtained from the similar studies are still controversial. With this study, we also aimed to contribute to this issue with our data. Since the outcomes and complication rate of PCNL were similar in both groups, this study showed that previous open surgery for renal stones on the same kidney does not adversely affect the results of PCNL.

\section{Authorship Contributions}

Ethics Committee Approval: Furkan Dursun, Informed Consent: Ferhat Ateş, Ömer Yılmaz, Concept: Hasan Soydan, Design: Temuçin Şenkul, Data Collection or Processing: Furkan Dursun, Ercan Malkoç, Analysis or Interpretation: Temuçin Şenkul, Literature Research: Hasan Soydan, Writing: Furkan Dursun, Peer-review: Internal peer- reviewed, Conflict of Interest: No conflict of interest was declared by the authors, Financial Disclosure: The authors declared that this study has received no financial support.

\section{References}

1. Alken P, Hutschenreiter G, Guenther R. Percutaneous kidney stone removal. Eur Urol 1982;8:304-311.

2. Turk C, Knoll T, Petrik A, Sarica K, Skolaris A, Straub M, Seitz C. Guidelines on urolithiasis. Eur As-soc Urol 2013:1-100.

3. http://www.us.elsevierhealth.com/urology/campbell-walsh-urologyexpert-consult/9781416069119/

4. Preminger GM, Clayman RV, Hardeman SW, Franklin J, Curry T, Peters PC. Percutaneous nephrostoli-thotomy vs open surgery for renal calculi: A comparative study. JAMA 1985;254:1054-1058.

5. Honeck $P$, Wendt-Nordahl G, Krombach $P$, Bach $T$, Häcker A, Alken $P$, Michel MS. Does open stone surgery still play a role in the treatment of urolithiasis? Data of a primary urolithiasis center. J Endourol 2009;23:1209-1212.

6. Paik ML, Resnick MI. Is there a role for open stone surgery? Urol Clin North Am 2000;27: 323-331.

7. Basiri A, Karrami H, Moghaddam SM, Shadpour P. Percutaneous nephrolithotomy in patients with or without a history of open nephrolithotomy. J Endourol 2003;17:213-216.

8. Sofikerim M, Demirci D, Gülmez I, Karacagil M. Does previous open nephrolithotomy affect the out-come of percutaneous nephrolithotomy? J Endourol 2007;21:401-403.

9. Margel D, Lifshitz DA, Kugel V, Dorfmann D, Lask D, Livne PM. Percutaneous nephrolithotomy in pa-tients who previously underwent open nephrolithotomy. J Endourol 2005;19:1161-1164.

10. Tugcu V, Su FE, Kalfazade N, Sahin S, Ozbay B, Tasci Al. Percutaneous nephrolithotomy (PCNL) in patients with previous open stone surgery. Int Urol Nephrol 2008;40:881-884.

11. Falahatkar S, Panahandeh Z, Ashoori E, Akbarpour M, Khaki N. What is the difference between percu-taneous nephrolithotomy in patients with and without previous open renal surgery? J Endourol 2009;23:1107-1110.

12. Knoll T, Michel MS, Alken P. Surgical atlas. Percutaneous nephrolithotomy: the Mannheim technique. BJU Int 2007;99:213-231.

13. Tefekli A, Ali Karadag $M$, Tepeler $K$, Sari E, Berberoglu $Y$, Baykal M, Sarilar 0 , Muslumanoglu AY. Classification of percutaneous nephrolithotomy complications using the modified clavien grading system: looking for a standard. Eur Urol 2008:53:184-190.

14. Jones DJ, Russell GL, Kellett MJ, Wickham JE. The changing practice of percutaneous stone surgery: Review of 1000 cases 1981-1988. Br J Urol 1990;66:1-5.

15. Vivile C. Percutaneous nephrolithotomy: Personal experience in 100 cases. J Urol (Paris) 1987:93:253-258.

16. Lojanapiwat B. Previous open nephrolithotomy: does it affect percutaneous nephrolithotomy techniques and outcome? J Endourol 2006;20:17-20. 